\title{
Large-Scale Production of Microalgal Lipids Containing High Levels of Docosahexaenoic Acid upon Fermentation of Aurantiochytrium sp. KRS101
}

\author{
Won-Kyung Hong ${ }^{1}$, Anna Yu ${ }^{1}$, Baek-Rock Oh ${ }^{1}$, Jang Min Park ${ }^{1}$, Chul Ho Kim ${ }^{1}$, Jung-Hoon Sohn², \\ Akihiko Kondo $^{3^{*}}$, Jeong-Woo Seo ${ }^{1^{*}}$ \\ ${ }^{1}$ Applied Microbiology Research Center, Bio-Materials Research Institute, Korea Research Institute of Bioscience and Biotechnol- \\ ogy (KRIBB), Jeongeup, South Korea; ${ }^{2}$ Systems and Synthetic Biology Research Center, Korea Research Institute of Bioscience and \\ Biotechnology (KRIBB), Daejeon, South Korea; ${ }^{3}$ Department of Chemical Science and Engineering, Graduate School of Engineer- \\ ing, Kobe University, Kobe, Japan. \\ Email: ${ }^{*}$ jwseo@kribb.re.kr
}

Received April $1^{\text {st }}, 2013$; revised May $2^{\text {nd }}, 2013$; accepted May $9^{\text {th }}, 2013$

Copyright (C) 2013 Won-Kyung Hong et al. This is an open access article distributed under the Creative Commons Attribution License, which permits unrestricted use, distribution, and reproduction in any medium, provided the original work is properly cited.

\begin{abstract}
In this study, large-scale production of microalgal lipid containing high levels of docosahexaenoic acid (DHA) by fermentation of Aurantiochytrium sp. KRS101 was performed. The microalgal strain yielded productivity of docosahexaenoic acid (DHA) productivity of 1.08 and $1.6 \mathrm{~g} / \mathrm{L} / \mathrm{d}$ by fermentation at $300-\mathrm{L}$ and $5000-\mathrm{L}$ scale stirrer-type bioreactor. The productivity was significantly enhanced upto $5.6 \mathrm{~g} / \mathrm{L} / \mathrm{d}$ by fermentation at $6000-\mathrm{L}$ scale airlift-type bioreactor, probably due to the reduced shearing force. The microalgal lipid could be efficiently recovered by safe extraction methods such as ethanol extraction, hot water extraction or supercritical fluid extraction, promising commercial potential of the microalgal DHA-rich lipid in the food and feed industry.
\end{abstract}

Keywords: Aurantiochytrium sp.; Heterotrophic Microalga; Large-Scale Cultivation; Lipid; Docosahexaenoic Acid

\section{Introduction}

Oleaginous microalga of the Thraustochytrid family may be valuable sources of oil because at least $30 \%$ of dry biomass is lipid, and the content of omega-3 polyunsaturated fatty acids (PuFA) is high [1]. This is especially true of docosahexaenoic acid (DHA, C22:6n-3) which plays key roles in development of the brain and eye $[2,3]$. Additionally, the high levels of desirable fatty acids render microbial oil valuable as a feedstock for production of biofuel.

Many oleaginous microalgal strains synthesizing high levels of PuFAs have been described [4]. Perveen et al. [5] characterized a Thraustochytrid-like microorganism (termed Strain 12B) that exhibited DHA productivity of $2.8 \mathrm{~g} / \mathrm{L} / \mathrm{d}$ upon shake flask cultivation. The highest DHA productivity $(3.7 \mathrm{~g} / \mathrm{L} / \mathrm{d})$ reported to date was attained upon fermentation of Schizochytrium limacinum SR21 in a laboratory scale bioreactor [6]. Large-scale fermentation of microalgal strain has also been reported; Schizochy-

${ }^{*}$ Corresponding authors. trium sp. HX-308 yielded DHA productivity values of 2.7 and $2.9 \mathrm{~g} / \mathrm{L} / \mathrm{d}$ when grown in 50-L and $1500-\mathrm{L}$ bioreactor, respectively [7].

Recently, we isolated and identified a novel Thraustochytrid microalga (termed Aurantiochytrium sp. KRS101) that produced high levels of lipid and DHA (over $45 \%$ total fatty acids) [8]. Upon fed-batch fermentation in a 5-L bioreactor, good biomass levels and lipid production values (50 and $22 \mathrm{~g} / \mathrm{L}$, respectively) were obtained; DHA productivity $(3.3 \mathrm{~g} / \mathrm{L} / \mathrm{d})$ comparable to that of S. limacinum SR21 [6]. To evaluate the comercial potential of such fermentation, large-scale growth of the microalgal strain was studied and the results are described in the present report. Also, it is worth extraction methods of fatty acid from fermentative sources in especially industrial fields. Considering both the economic feasibility in industry and the safety of food additives, the relevant interest for this molecule and its biological activity, and starting from the consideration that better methods for the characterization and determination of fatty acid are needed, it is to propose a proper method for 
the extraction and characterization of fatty acid from fermentative microalgae product.

\section{Materials and Methods}

\subsection{Microalgal Strain and Media}

Details of the Thraustochytrid microalgal strain Aurantiochytrium sp. KRS101 was previously reported [8]. The microalga was cultivated in 5-L baffled flasks containing $50 \mathrm{~mL}$ of basal medium [glucose (food grade), $60 \mathrm{~g} / \mathrm{L}$; yeast extract (food grade), $10 \mathrm{~g} / \mathrm{L}$; dried natural sea salt (CJ Co., Korea), $10 \mathrm{~g} / \mathrm{L}$ ] at $28^{\circ} \mathrm{C}$, with shaking at 120 rpm, for $3 \mathrm{~d}$.

\subsection{Fermentation of Aurantiochytrium sp. KRS101}

Cells were precultured in $5 \mathrm{~L}$ amounts of basal medium, with shaking at $120 \mathrm{rpm}$, for $3 \mathrm{~d}$ at $28^{\circ} \mathrm{C}$. Precultures were transferred at $2.5 \%(\mathrm{v} / \mathrm{v})$ of fermenter medium volume into 300 -L bioreactor, or (in later work) into 5000-L stirrer-type and 6000-L airlift-type bioreactors. Culture aliquots were collected every $12 \mathrm{~h}$ for analysis of growth via measurement of absorbance at $600 \mathrm{~nm}$. The fermentation conditions in the $300-\mathrm{L}$ bioreactor were $28^{\circ} \mathrm{C}$, stirring at $50 \mathrm{rpm}, 0.5 \mathrm{v} / \mathrm{v} / \mathrm{min}$ of air, and $\mathrm{pH} 7.0$.

\subsection{Lipid Extraction}

For ethanol extraction, cell paste was sonicated for $5 \mathrm{~min}$ (each pulse was $5 \mathrm{~s}$ in duration followed by $5 \mathrm{~s}$ on ice on $300 \mathrm{~W}, 20 \mathrm{kHz}$ ) and added ethanol to final $50 \%$. After centrifugation at $10,000 \mathrm{~g}$ for $5 \mathrm{~min}$, the ethanol phase containing lipid was collected by rotary evaporation than analyzed fatty acid and its composition. For hot water extraction, cell paste was autoclaved at $121^{\circ} \mathrm{C}$ for $30 \mathrm{~m}$ and the liquid phase was collected than analyzed further process. The supercritical fluid (SCF) extraction was performed on $300 \mathrm{bar}, 60^{\circ} \mathrm{C}$ and $180 \mathrm{~m}$. Three independent experiments at least of all extraction process were made for each end-point.

\subsection{Dry Cell Weight Analysis}

Dry cell weight $(\mathrm{DCW})$ was estimated by harvesting cells at $4500 \mathrm{~g}$ at $4^{\circ} \mathrm{C}$ for $20 \mathrm{~m}$. Each supernatant was discarded and each pellet washed three times with phosphate-buffered saline (PBS, pH 7.2). Resuspended cells were again harvested by centrifugation at $4500 \mathrm{~g}$ at $4^{\circ} \mathrm{C}$ for $20 \mathrm{~min}$. Each pellet was resuspended in $600 \mu \mathrm{L}$ distilled water and transferred to a pre-weighed vial. Cell pellets were dried at $60^{\circ} \mathrm{C}$ for $12 \mathrm{~h}$ using a speed vacuum concentrator (Biotron 4080C). Each vial was weighed and $\mathrm{DCW}$ value estimated.

\subsection{Lipid Analysis}

Total lipid content was calculated using a modified (miniaturized) Bligh-Dyer method as described by Burja et al. [9]. Dried cells (125 mg amounts) were placed in screw-cap test tubes, and $6.25 \mathrm{~mL}$ chloroform, $12.5 \mathrm{~mL}$ methanol, and $5 \mathrm{ml} 50 \mathrm{mM} \mathrm{K} \mathrm{HPO}_{4}$ buffer (pH 7.4) were added to each tube. Samples were agitated for $1 \mathrm{~h}$, shaking at $200 \mathrm{rpm}$, at $28^{\circ} \mathrm{C}$. Each sample was next transferred to a $50 \mathrm{~mL}$ graduated tube, and $6.25 \mathrm{~mL}$ chloroform and $6.25 \mathrm{~mL}$ phosphate buffer were added. Each tube was inverted 30 times and the phases allowed to separate for $1 \mathrm{~h}$ before recovery of the bottom layer (approximately $12.5 \mathrm{~mL}$ ). This liquid was transferred to a preweighed aluminum dish and the solvent was evaporated over $30 \mathrm{~m}$ in a dry oven to $80^{\circ} \mathrm{C}$. After cooling, the dish and contents were weighed, and total lipid levels were determined gravimetrically (to yield the weight of lipid extracted) using the following equation:

$$
\begin{aligned}
& \text { Total lipid (g of oil per } 100 \text { gsample) } \\
& =\left[\left(\mathrm{W}_{\mathrm{L}}-\mathrm{W}_{\mathrm{D}}\right) \times \mathrm{V}_{\mathrm{C}} \times 100\right] /\left[\mathrm{V}_{\mathrm{P}} \times \mathrm{W}_{\mathrm{S}}\right]
\end{aligned}
$$

where $\mathrm{W}_{\mathrm{D}}$ was the weight of an empty aluminum dish (g); $\mathrm{W}_{\mathrm{L}}$ the weight of an aluminum dish with dried lipid residue $(\mathrm{g}) ; \mathrm{W}_{\mathrm{S}}$ the weight of sample $(\mathrm{g}) ; \mathrm{V}_{\mathrm{C}}$ the total volume of chloroform in the graduated cylinder $(\mathrm{mL})$; and $\mathrm{V}_{\mathrm{P}}$ the volume of chloroform transferred to the aluminum dish $(\mathrm{mL})$.

\subsection{Analysis of Fatty Acid Composition}

Dried cells were resuspended in $3 \mathrm{~mL} 4 \%(\mathrm{v} / \mathrm{v})$ methanolic sulfuric acid and heated at $90^{\circ} \mathrm{C}$ for $1 \mathrm{~h}$ in sealed vials. Fatty acid methyl esters (FAMEs) were extracted into 0.3 $\mathrm{mL}$ hexane and analyzed via gas chromatography (GC; Hewlett Packard 6890 N; Ramsey, MN); the instrument was equipped with a flame-ionization detector (FID) and an HP-5 (30 m $\times 0.32 \mathrm{~mm}$; $0.25 \mathrm{~mm}$; Agilent Technologies; Santa Clara, CA). The column temperature was raised from $150^{\circ} \mathrm{C}$ (after $2 \mathrm{~min}$ of holding) to $270^{\circ} \mathrm{C}$ (with a further $2 \mathrm{~m}$ of holding) at a rate of $7^{\circ} \mathrm{C}$ per min.

\section{Results and Discussion}

\subsection{Production of Microalgal Lipid by Cultivation of Aurantiochytrium sp. KRS101 in sTirrer-Type Bioreactor}

The oleaginous microalga Aurantiochytrium sp. KRS101 was first cultivated in a 300-L stirrer-type bioreactor in a working volume of $150 \mathrm{~L}$ of medium. As shown in Figure 1, glucose was completely consumed after $60 \mathrm{~h}$ of cultivation, yielding $11.8 \mathrm{~g} / \mathrm{L}$ of DCW. The level of lipid in the cells was $4.9 \mathrm{~g} / \mathrm{L}$, indicating that conversion of glucose to lipid was rather low $(7.3 \%, g / g)$. However, the 


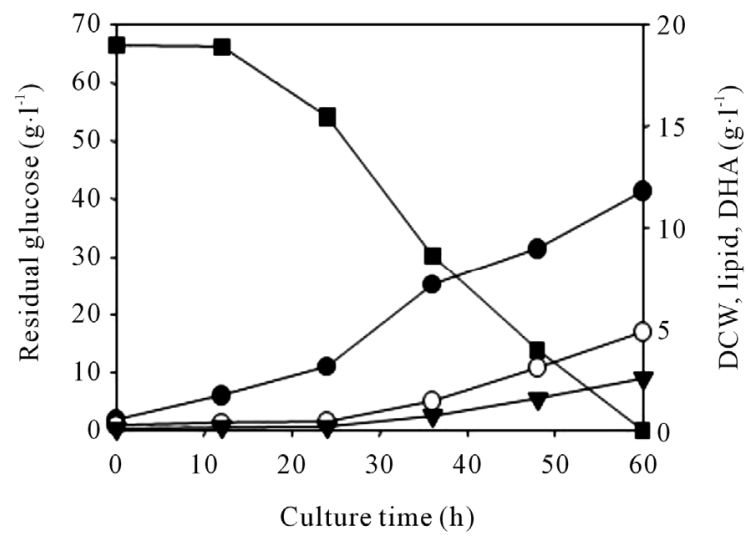

Figure 1. Cultivation of Aurantiochytrium sp. KRS101 in a 500-L bioreactor. Closed circles, dry cell weights; open circles, lipid contents; closed triangles, DHA contents; closed squares, residual glucose levels.

DHA level in the microalgal lipid was extremely high (over $50 \%$ of total fatty acids). The DHA productivity level was $1.08 \mathrm{~g} / \mathrm{L} / \mathrm{d}$.

Next, to determine whether the microalgal lipid could be produced in pilot-scale fermentation, the microalgal strain was cultivated in a $3000 \mathrm{~L}$ volume in a $5000-\mathrm{L}$ scale stirrer-type bioreactor. The strain grew well upon large-scale fermentation, yielding a DCW of $30.5 \mathrm{~g} / \mathrm{L}$ after $48 \mathrm{~h}$ of cultivation (Figure 2). The lipid level in cells was $8.2 \mathrm{~g} / \mathrm{L}$; the conversion rate of glucose to lipid was $19.6 \%(\mathrm{~g} / \mathrm{g})$. The DHA level and DHA productivity were $39.5 \%$ and $1.6 \mathrm{~g} / \mathrm{L} / \mathrm{d}$, respectively (Table 1 ).

The DHA productivity values obtained in stirrer-type bioreactor, 1.08 and $1.6 \mathrm{~g} / \mathrm{L} / \mathrm{d}$ at $300-\mathrm{L}$ and $5000-\mathrm{L}$ scale bioreactors, respectively, were much less than seen upon laboratory scale fermentation in a 5-L stirrer-type bioreactor $(3.3 \mathrm{~g} / \mathrm{L} / \mathrm{d})$; the latter value was comparable to the highest level $(3.7 \mathrm{~g} / \mathrm{L} / \mathrm{d})$ of DHA productivity yet reported (upon fermentation of S. limacinum SR21) [6].

\subsection{Pilot-Scale Production of Microalgal Lipid Using a 6000-L Airlift-Type Bioreactor}

To examine whether the microalgal lipid production was affected by bioreactor type, an airlift-type bioreactor was employed. Notably, when the microalgal strain was cultivated in a $6000-\mathrm{L}$ scale airlift-type bioreactor $(3000 \mathrm{~L}$ working volume), cell growth $(\mu ; 0.090 / \mathrm{h})$ and glucose consumption rate (qs; $0.115 / \mathrm{h}$ ) were much higher than the values obtained upon fermentation in stirrer-type vessels $(0.057 / \mathrm{h}$ and $0.064 / \mathrm{h}$, respectively) (Figure 3). And the rate of lipid accumulation, and the final level were two-fold higher upon airlift-type fermentation (qp; $0.060 / \mathrm{h}$ and $16.3 \mathrm{~g} / \mathrm{L}$, respectively) than was the case when stirrer-type vessels were employed (qp; 0.039/h and $8.2 \mathrm{~g} / \mathrm{L}$, respectively). Subsequently, the final DHA

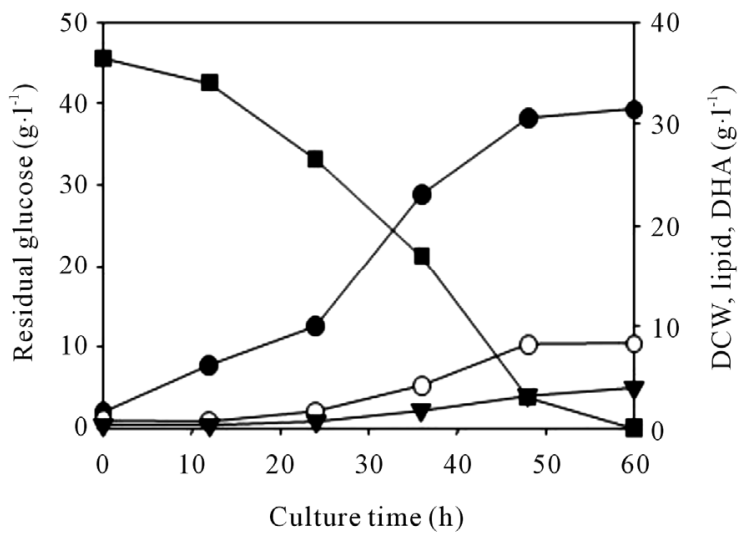

Figure 2. Cultivation of Aurantiochytrium sp. KRS101 in a 5000-L stirrer-type bioreactor. Closed circles, dry cell weights; open circles, lipid contents; closed triangles, DHA contents; closed squares, residual glucose levels.

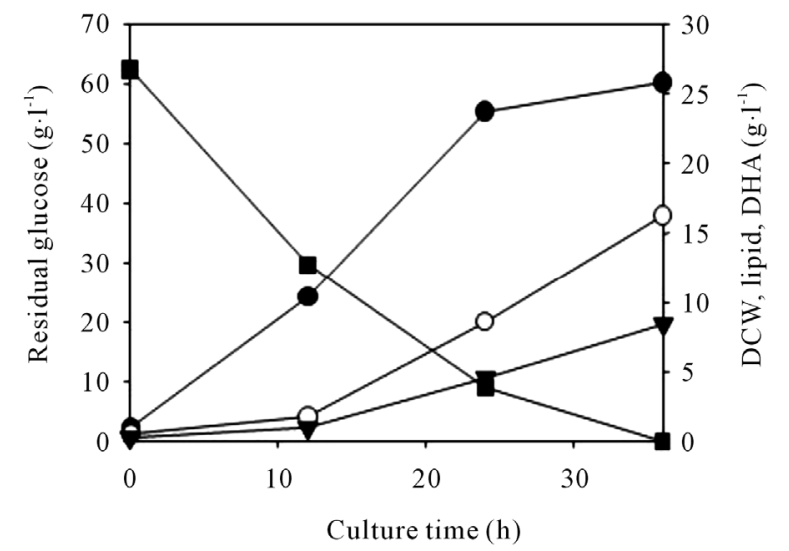

Figure 3. Cultivation of Aurantiochytrium sp. KRS101 in a 6000-L airlift-type bioreactor. Closed circles, dry cell weights; open circles, lipid contents; closed triangles, DHA contents; closed squares, residual glucose levels.

Table 1. Comparison of lipid production parameters upon large-scale cultivation of Aurantiochytrium sp. KRS101 in different types of bioreactors.

\begin{tabular}{ccc}
\hline & $\begin{array}{c}\text { Stirrer-type } \\
(5000-\mathrm{L} \text { scale })\end{array}$ & $\begin{array}{c}\text { Airlift-type } \\
(6000-\mathrm{L} \text { scale })\end{array}$ \\
\hline Lipid conversion rate $\left(\mathrm{g} \cdot \mathrm{g}^{-1}\right.$ glucose $)$ & 0.196 & 0.262 \\
Lipid productivity $\left(\mathrm{g} \cdot \mathrm{L}^{-1} \cdot \mathrm{day}^{-1}\right)$ & 4.08 & 10.8 \\
DHA content $(\%$ total fatty acids $)$ & 39.5 & 52.3 \\
\hline
\end{tabular}

level obtained was higher upon airlift-type fermentation (Table 1). As the result, the DHA productivity was significantly elevated in the airlift-type bioreactor fermentation upto $5.6 \mathrm{~g} / \mathrm{L} / \mathrm{d}$, which could be due to the decrease of shearing force in the airlift type.

When the commercial strain S. limacinum SR21 was employed to this end, the maximum DHA productivity 
noted was $13.1 \mathrm{~g} / \mathrm{L} / \mathrm{d}$ upon fed-batch fermentation (in a volume of 14,000 gallons), after optimization of aeration [10]. Therefore, it may be expected that DHA productivity of Aurantiochytrium sp. KRS101 will be enhanced upon optimization of fermentation conditions.

\subsection{Extraction of Microalgal Lipid Containing High Levels of Docosahexaenoic Acid}

Four extraction methods were compared to recover DHArich microalgal lipid, i.e. the typical chloroform-methanol extraction method of Bligh-Dyer [9], ethanol extraction method with sonication, supercritical carbon dioxide extraction method [11] and hot water extraction method. The highest levels of lipid and docosahexaenoic acid was recovered from microalgal cells by chloroform-methanol extraction method recovered from microalgal cells were $58.7 \% \pm 1.2 \%$ of DCW and $47.4 \% \pm 1.1 \%$ of TFA by chloroform-methanol extraction method (Table 2). Aspect of the applications [12] of the microalgal lipid in food and feed industries, more safe extraction methods would be preferred. Ethanol extraction after ultrasonication gave approximately $90 \%$ extraction yield compared to that of the chloroform-methanol extraction method (Table 2). Whereas, supercritical carbon dioxide extraction method and hot water extraction methods resulted in much less $68 \%$ and $62 \%$ recovery yield compared to that of the chloroform-methanol extraction method. The composition of fatty acid in the lipids recovered was similar from four extraction methods (Table 2).

\section{Conclusion}

In this study, large-scale production of microalgal lipid containing high levels of DHA was successfully performed using $6000-\mathrm{L}$ airlift-type bioreactor. The maximal productivity of DHA in the experiment reached at $5.6 \mathrm{~g} / \mathrm{L} / \mathrm{d}$, which, to the best of our knowledge, is the highest productivity value yet reported. The microalgal lipid was effectively recovered by safe extraction methods applicable for food and feed industry. Thus, the mi-

Table 2. Comparison of lipid recovery by different lipid extraction method with pilot-scale fermentative microalgae product of Aurantiochytrium sp. KRS101.

\begin{tabular}{ccc}
\hline & $\begin{array}{c}\text { Oil recovery } \\
\text { of DCW (\%) }\end{array}$ & $\begin{array}{c}\text { DHA content } \\
\text { of TFA (\%) }\end{array}$ \\
\hline Chloroform-methanol extraction & $58.7 \pm 1.2$ & $47.4 \pm 1.1$ \\
Ethanol extraction with sonication & $53.2 \pm 1.1$ & $43.5 \pm 1.2$ \\
Supercritical carbon dioxide extraction & $40 \pm 1.2$ & $41 \pm 1.1$ \\
Hot water extraction & $36.3 \pm 1.7$ & $44 \pm 0.9$ \\
\hline
\end{tabular}

Data are expressed as means $\pm \mathrm{SD}$. Three independent experiments were made for each end-point. croalgal lipid would serve as a valuable source of PuFAs.

\section{Acknowledgements}

This work was supported the Advanced Biomass R\&D Center (2010-0029737) of Korea Grant funded by the Ministry of Education, Science and Technology and by the Ministry of Food, Agriculture, Forestry, and Fisheries of the Republic Korea.

\section{REFERENCES}

[1] Y. Li, Z. Zhao and F. Bai, "High-Density Cultivation of Oleaginous Yeast Rhodosporidium toruloides Y4 in Fed-Batch Culture," Enzyme and Microbial Technology, Vol. 41, No. 3, 2007, pp. 312-317. doi:10.1016/j.enzmictec.2007.02.008

[2] M. Abbey, P. Clifton, M. Kestin, B. Belling and P. Nestel, "Effect of Fish Oil on Lipoproteins, Lecithin: Cholesterol Acyltransferase, and Lipid Transfer Protein Activity in Humans," Arteriosclerosis, Vol. 10, No. 1, 1990, pp. 85-94. doi:10.1161/01.ATV.10.1.85

[3] L. Lauritzen, H. S. Hansen, M. H. Jorgensen and K. F. Michaelsen, "The Essentiality of Long Chain $\omega-3$ Fatty Acids in Relation to Development and Function of the Brain and Retina," Progress in Lipid Reearchs, Vol. 40, No. 1, 2001, pp. 1-94. doi:10.1016/S0163-7827(00)00017-5

[4] Y. L. Ma, "Microbial Oils and Its Research Advance," Chinese Journal of Bioprocess Engineering, Vol. 4, 2006, pp. 7-11.

[5] Z. Perveen, H. Ando, A. Ueno, Y. Ito, Y. Yamamoto, Y. Yamada, T. Takagi, T. Kaneko, K. Kogame and H. Okuyama, "Isolation and Characterization of a Novel Thraustochytrid-Like Microorganism that Efficiently Produces Docosahexaenoic Acid," Biotechnology Letters, Vol. 28, No. 3, 2006, pp. 197-202. doi:10.1007/s10529-005-5335-4

[6] S. M. Rosa, M. A. Soria, C. G. Velez and M. A. Galvagno, "Improvement of a Two-Stage Fermentation Process for Docosahexaenoic Acid Production by Aurantiochytrium limacinum SR21 Applying Statistical Experimental Designs and Data Analysis," Bioresource Technology, Vol. 101, No. 7, 2010, pp. 2367-2374. doi:10.1016/j.biortech.2009.11.056

[7] L. J. Ren, X. J. Ji, H. Huang, L. Qu, Y. Feng, Q. Q. Tong and R. K. Ouyang, "Development of a Stepwise Aeration Control Strategy for Efficient Docosahexaenoic Acid Production by Schizochytrium sp.," Applied Microbiology and Biotechnology, Vol. 87, No. 5, 2010, pp. 1649-1656. doi:10.1007/s00253-010-2639-7

[8] W. K. Hong, D. Rairakhwada, P. S. Seo, S. Y. Park, B. K. Hur, C. H. Kim and J. W. Seo, "Production of Lipids Containing High Levels of Docosahexaenoic Acid by a Newly Isolated Microalga, Auratiochytrium sp. KRS101," Applied Microbiology and Biotechnology, Vol. 164, No. 8, 2011, pp. 1468-1480.

[9] A. M. Burja, H. Radianingtyas, A. Windust and C. J. 
Barrow, "Isolation and Characterization of Polyunsaturated Fatty Acid Producing Thraustochytrium Species: Screening of Strains and Optimization of Omega-3 Production," Applied Microbiology and Biotechnology, Vol. 72, No. 6, 2003, pp. 1161-1169. doi:10.1007/s00253-006-0419-1

[10] R. B. Bailey, D. DiMasi, J. M. Hansen, P. J. Mirrasoul, C. M. Ruecker, G. T. Veeder, T. Kaneko and W. R. Barclay, "Enhanced Production of Lipids Containing Polyenoic Fatty Acid by Very High Density Cultures of Eukaryotic Microbes in Fermentors," US Patent 6607900 B2, 2003.
[11] M. S. Uddin, H. Kishimura and B. S. Chun, "Isolation and Characterization of Lecithin from Squid (Todarodes pacificus) Viscera Deoiled by Supercritical Carbon Dioxide Extraction," Journal of Food Science, Vol. 76, No. 2, 2011, pp. c350-c354. doi:10.1111/j.1750-3841.2010.02039.x

[12] A. M. Sanghvi and Y. M. Lo, "Present and Potential Industrial Applications of Macro- and Microalgae," Recent Patents on Food, Nutrition and Agriculture, Vol. 2, No. 3, 2010, pp. 187-194. 